\title{
BIOEDUSCIENCE
}

ISSN: 2614-1558

\section{Diversity of Parasitoid Insects (Order: Hymenoptera) in Rice Field and Vegetable Garden}

\author{
Manap Trianto ${ }^{1,3 *}$, Varsha Salsabillah ${ }^{2,3}$ \\ ${ }_{1}^{1}$ Department of Tropical Biology, Faculty of Biology, Universitas Gadjah Mada, Jl. Teknika Selatan, Sekip Utara, Bulaksumur, Sleman, 55281, \\ Yogyakarta, Indonesia \\ 2Department of Plant Protection, Faculty of Agriculture, Universitas Gadjah Mada, Jl. Flora, Bulaksumur, Karang Malang, Sleman, 55281, \\ Yogyakarta, Indonesia \\ ${ }^{3}$ Forum Sains dan Teknologi (FOST), Himpunan Mahasiswa Pascasarjana, Universitas Gadjah Mada, Bulaksumur, Caturtunggal, Sleman, \\ 55281, Yogyakarta, Indonesia \\ *Corespondent Email: manaptrianto@mail.ugm.ac.id
}

\section{ARTICLE INFO}

\section{Article history}

Received: 18 Jun 2020

Accepted: 02 Des 2020

Published: 30 Apr 2021

\section{Keywords:}

Diversity

Parasitoid insects

Hymenoptera

Rice fields

Vegetable gardens

\section{A B S T R A C T}

Background: The Hymenoptera Order is one of the most dominant orders in the insect class, both in the number of species and in their distribution in various habitats. The role of the Hymenoptera Order, especially parasitoids, is crucial in a habitat. This study aimed to determine the diversity of parasitoid insects, especially Hymenoptera, in rice and vegetable gardens. Methods: This research is analytic descriptive. The research method used is a line transect using a sampling technique. The study was conducted in two research areas (rice fields and vegetable gardens) and used three fishing gears (malaise traps, buckets, and insect nets). Results: The results showed that the total number of insects caught was 5037 individuals from 10 orders and 80 families. In this study, the diversity of parasitoid insects is in the rice fields $\mathrm{H}^{\prime}=1.80$ (moderate diversity) and vegetable gardens $\mathrm{H}^{\prime}=2.26$ (average diversity). Conclusions: Hymenoptera parasitoid insect diversity was highest in the vegetable garden area.

\section{Keanekaragaman Serangga Parasitoid (Ordo: Hymenoptera) Pada Areal Persawahan dan} Kebun Sayur

\section{A B S T R A K}

Background: Ordo Hymenoptera merupakan salah satu ordo yang paling dominan dalam kelas serangga, baik dalam jumlah spesies dan dalam penyebarannya di berbagai habitat. Peranan ordo Hymenoptera, khususnya parasitoid, sangat penting di dalam suatu habitat. Tujuan dari penelitian ini adalah untuk mengetahui keanekaragaman serangga parasitoid khususnya ordo Hymenoptera pada areal perasawahan dan kebun sayur. Metode: Penelitian bersifat deskriptif analitik. Metode penelitian yang digunakan adalah transek garis dengan menggunakan teknik sampling. Penelitian dilakukan di dua area penelitian (persawahan dan kebun sayur) dan menggunakan tiga alat tangkap (perangkap malaise, ember, dan jaring serangga). Hasil: Hasil penelitian menunjukkan bahwa jumlah seluruh serangga yang tertangkap yaitu sebanyak 5037 individu yang berasal dari 10 Ordo dan 80 famili. Keanekaragaman serangga parasitoid dalam penelitian ini yaitu pada areal persawahan $H^{\prime}=1,80$ (keanekaragaman sedang) dan kebun sayur $\mathrm{H}^{\prime}=2,26$ (keanekaragaman sedang). Kesimpulan: Keanekaragaman serangga parasitoid ordo Hymenoptera tertinggi pada penelitian ini yaitu pada area kebun sayur.

(C2021 by authors. License Bioeduscience, UHAMKA, Jakarta. This article is open access distributed under the terms and conditions of a Creative Commons Attribution (CC-BY) license.

\section{Introduction}

Community structure is a concept that studies the composition or composition of species and their abundance in a community. In general, three approaches can describe the community structure in a region: species diversity, species interactions, and functional organization (Cadotte et al., 2011; Sukmawati et al., 2020; Trianto and Marisa, 2020; Trianto et al., 2020). 
Species diversity is the diversity of organisms that occupy an ecosystem both on land and in the oceans (Brown, 2014; Trianto et al., 2020). Indonesia is one of the regions with high species diversity so that it is called one of the twelve mega biodiversity countries in the world (Buchori, 2014). The diversity of insects in a habitat varies depending on plant factors, climatic conditions, and habitat conditions. The existence of forests as natural habitats provides a higher and more complex number and diversity of insects than agroecosystems (Udawatta et al., 2019).

Rice fields and vegetable gardens are suitable types of agroecosystem for the development of insects, one of which is the parasitoid insects of the order Hymenoptera (Godfray, 1994). The Hymenoptera order is one of the insect orders that are most beneficial to humans compared to other charges in the insect class. For example, as a pollinator or flower pollinator, as a producer of honey and as a parasitoid (Borror et al., 1996). Parasitoids are very potential biological control agents in nature. The use of parasitoids as natural enemies in agriculture is constructive in controlling pests that damage agricultural commodities. The use of parasitoids has several advantages compared to other control techniques, they can prevent specific problems, and their population in the field is relatively high (Widnyana, 2012; Nuraini et al., 2020; Pratama and Trianto, 2020).

Seeing the importance of the role of the Hymenoptera order parasitoid insects in an area, it is necessary to know the types and diversity, such as in vegetable gardens and rice fields, which are one of the economic resource areas for people who are vulnerable to pests. This data can later be used as initial information before making use of parasitoid insects as pest control. This study aims to determine the diversity of parasitoid insects, especially the order Hymenoptera, in rice fields and vegetable gardens in maximizing the role of ecosystem diversity in a habitat to achieve a balance of natural ecosystems and reduce the population of pest ecosystems that can harm agroecosystems.

\section{Method}

This research was carried out from April until May 2019 in rice field and vegetable garden in Martapura sub-district, Banjar District, South Kalimantan Province (Figure 1) (Table 1).

The tools and materials in this research is malaise trap measuring $1 \mathrm{~m} \mathrm{x} 1 \mathrm{~m} \mathrm{x} 1 \mathrm{~m}$, insect nets $45 \mathrm{~cm} \times 70 \mathrm{~cm}$, and a bucket measuring $30 \mathrm{~cm}$, parasitoid insects, bottle sample, alcohol 70\%, ropes, Chirurgie tweezers $12 \mathrm{~cm}$, pinning insect $0.1 \mathrm{~mm}$, Schott Duran Petri dishes $10 \mathrm{~cm}$, styrofoam $60 \mathrm{~cm} \times 60 \mathrm{~cm}$, brush sizes 3/0, and label paper.
Determination of sampling sites using a roaming method. Insects from two research areas are obtained from three kinds of collection tools. First, in every research area are instaled with 25 buckets. Every bucket is placed on a transect line diagonally with a $1 \mathrm{~m}$ gap between the bucket (Perdana, 2010) (Figure 2). Second, the malaise trap also instaled. The trap is left for three days. Third, the insect is collected by using an insect net and swing 50 times for every area. One swing is going to left and right. Collecting sample is done three times with seven days time span. Obtained insect than picked by pin-set and save in the brothel which contained alcohol $70 \%$

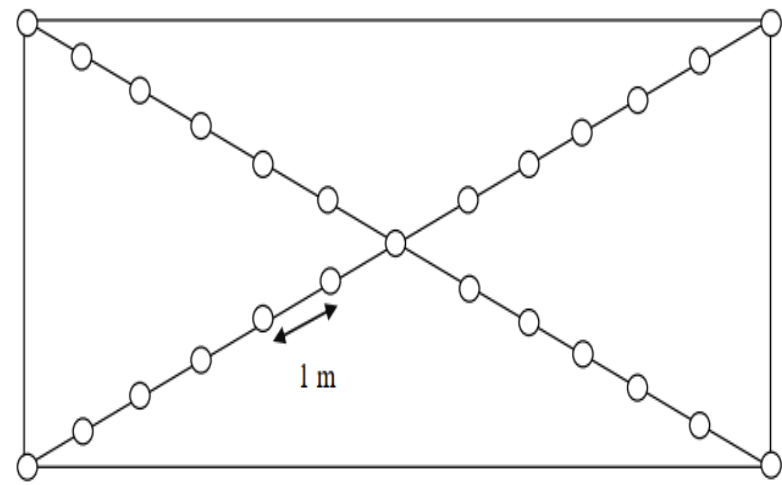

Figure 2. Sampling scheme. A circle is a bucket with a distance of $1 \mathrm{~m}$ for each bucket.

Sample bottle which contained insect from research area labelled by period, places and traps, every insect are identified by the family using several "kunci determinasi", namely Borror et al. (1996). Insect of Diptera is identified from McAlpine (1981). For insect of Hymenoptera are determined by "kunci" from Gibson (1993).

\section{Data Analysis}

Data analysis was performed by calculating the Shannon diversity index and its distribution (Evenness) (Magurran, 1996). The following formula calculates the Shannon diversity index:

Shannon-Wiener index:

Information:

$$
H^{\prime}=-\sum(n i / N) \ln (n i / N)
$$

$\mathrm{H}^{\prime} \quad$ : Diversity index

ni : Number of individuals

$\mathrm{N} \quad$ : Total number of individuals

\section{Shannon-Evennes index}

Information:

$$
\mathrm{E}=\mathrm{H}^{\prime} / \ln \mathrm{S}
$$

E : Evenness index

$\mathrm{H}^{\prime}$ : Diversity index

S : Number of species 


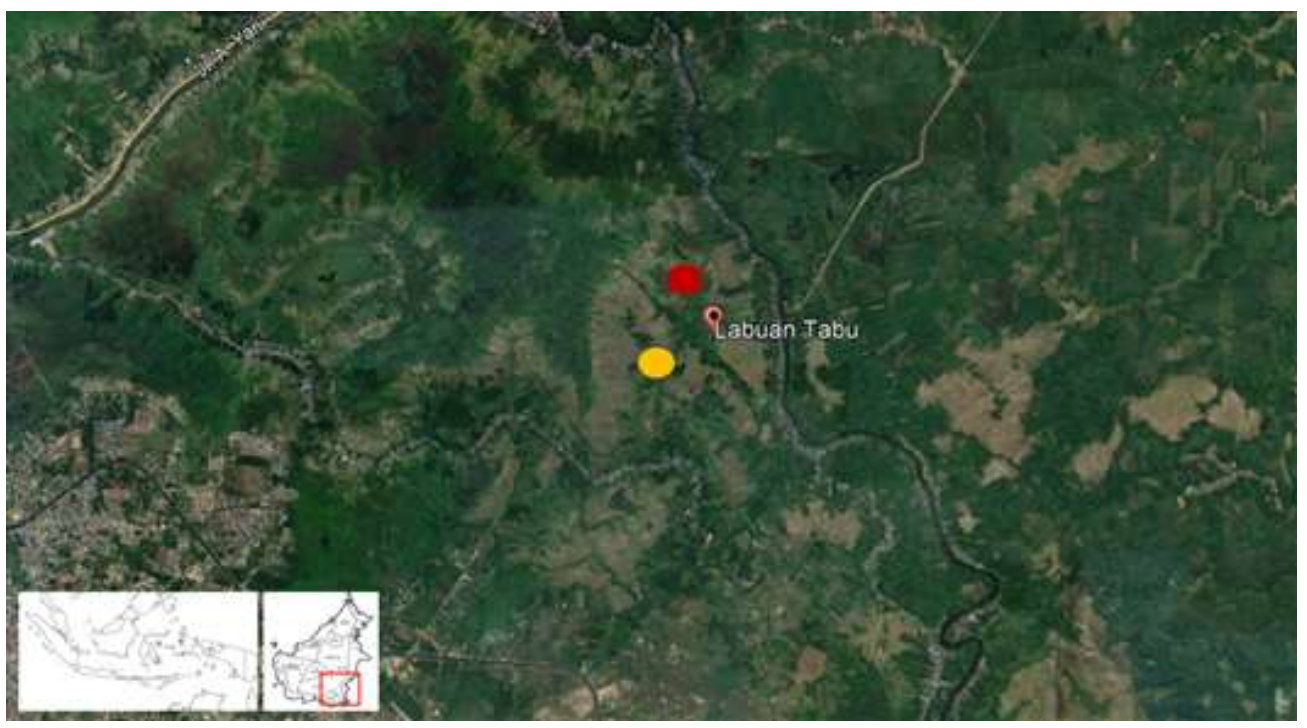

Figure 1. Sampling location; Red color (rice field area) and yellow color (vegetable garden area)

Table 1. Coordinate point of research location

\begin{tabular}{clcl}
\hline No & Location & Coordinate & \multicolumn{1}{c}{ Location Conditions } \\
\hline 1 & Rice field & $3^{\circ} 24^{\prime} 35.92^{\prime \prime} \mathrm{S} 114^{\circ} 54^{\prime} 36.56^{\prime \prime} \mathrm{E}$ & $\begin{array}{l}\text { The rice fields are planted with inpara rice varieties. There are } \\
\text { various types of weeds such as grasses, sedges and broad leaves. } \\
\text { The vegetable garden is planted with several types of vegetables } \\
\text { such as mustard greens, eggplant and long beans produced in } \\
\text { groups (plots) based on the type of vegetables. }\end{array}$ \\
\hline $\begin{array}{l}\text { Vegetable } \\
\text { garden }\end{array}$ & $3^{\circ} 24^{\prime} 35.76^{\prime \prime} \mathrm{S} 114^{\circ} 54^{\prime} 36.42^{\prime \prime} \mathrm{E}$ \\
\hline
\end{tabular}

\section{Results}

Order, family and individual of parasitoids insect based on the research area and catching tools

The number of insects obtained in the research area is 307 individual, originated from 10 order and 80 families (Table 2). Three of the dominant order founded have consisted of Diptera (70,30\%), Hymenoptera (12,67\%) and
Hemiptera $(9,99 \%)$ (Figure 2). Furthermore, the number of Hymenoptera individuals in the rice field is lowest compared to the Vegetable garden (Table 2). Whereas, obtained number of individuals and family of Hymenoptera by used bucket tool (3436 individuals, 51 families) are highest than malaise trap (1385 individuals, 21 families) and insect net (189 individuals and 8 families) (Table 3).

Table 2. Number of orders, family and individuals of insects by research areas

\begin{tabular}{|c|c|c|c|c|c|c|c|}
\hline \multirow{2}{*}{ No. } & \multirow{2}{*}{ Order } & \multicolumn{2}{|c|}{ Number of Families } & \multirow[t]{2}{*}{ Total } & \multicolumn{2}{|c|}{ Number of Individuals } & \multirow[t]{2}{*}{ Total } \\
\hline & & $\mathrm{S}$ & KS & & $\mathrm{S}$ & KS & \\
\hline 1 & Hymenoptera & 21 & 22 & 32 & 160 & 478 & 638 \\
\hline 2 & Coleoptera & 5 & 2 & 5 & 41 & 76 & 117 \\
\hline 3 & Lepidoptera & 3 & 3 & 4 & 14 & 21 & 35 \\
\hline 4 & Trichoptera & 0 & 1 & 1 & 2 & 4 & 6 \\
\hline 5 & Odonata & 1 & 1 & 2 & 3 & 5 & 8 \\
\hline 6 & Diptera & 16 & 15 & 22 & 972 & 2569 & 3541 \\
\hline 7 & Hemiptera & 5 & 4 & 6 & 142 & 361 & 503 \\
\hline 8 & Orthoptera & 5 & 4 & 6 & 142 & 361 & 111 \\
\hline 9 & Psocoptera & 0 & 1 & 1 & 38 & 73 & 69 \\
\hline 10 & Thysanoptera & 1 & 1 & 1 & 30 & 39 & 9 \\
\hline & Total & 57 & 54 & 80 & 1406 & 3631 & 5037 \\
\hline
\end{tabular}

Information: $\mathrm{S}$ = Rice field, and KS = Vegetable gardens

Table 3. Number of families and individual insect based on catching tools

\begin{tabular}{|c|c|c|c|c|c|c|c|c|c|}
\hline \multirow{2}{*}{ No. } & \multirow{2}{*}{ Order } & \multicolumn{3}{|c|}{ Number of Families } & \multirow{2}{*}{ Total } & \multicolumn{3}{|c|}{ Number of Individuals } & \multirow{2}{*}{ Total } \\
\hline & & PM & $E$ & JS & & PM & $E$ & JS & \\
\hline 1 & Hymenoptera & 8 & 21 & 3 & 32 & 191 & 349 & 98 & 638 \\
\hline 2 & Coleoptera & 2 & 3 & 0 & 5 & 25 & 87 & 5 & 117 \\
\hline 3 & Lepidoptera & 1 & 2 & 1 & 4 & 9 & 19 & 7 & 35 \\
\hline 4 & Trichoptera & 0 & 1 & 0 & 1 & 1 & 5 & 0 & 6 \\
\hline 5 & Odonata & 0 & 2 & 0 & 2 & 2 & 5 & 1 & 8 \\
\hline 6 & Diptera & 6 & 13 & 3 & 22 & 1005 & 2511 & 25 & 3541 \\
\hline
\end{tabular}




\begin{tabular}{cccccccccc}
7 & Hemiptera & 2 & 3 & 1 & 6 & 106 & 368 & 29 & 503 \\
8 & Orthoptera & 2 & 4 & 0 & 6 & 28 & 71 & 12 & 111 \\
9 & Psocoptera & 0 & 1 & 0 & 1 & 15 & 43 & 11 & 69 \\
10 & Thysanoptera & 0 & 1 & 0 & 1 & 3 & 5 & 1 & 9 \\
& Total & 21 & 51 & 8 & 80 & 1385 & 3463 & 189 & 5037 \\
\hline
\end{tabular}

Information: PM = Malaise trap, $\mathrm{E}=$ Bucket, and JS = Insect net

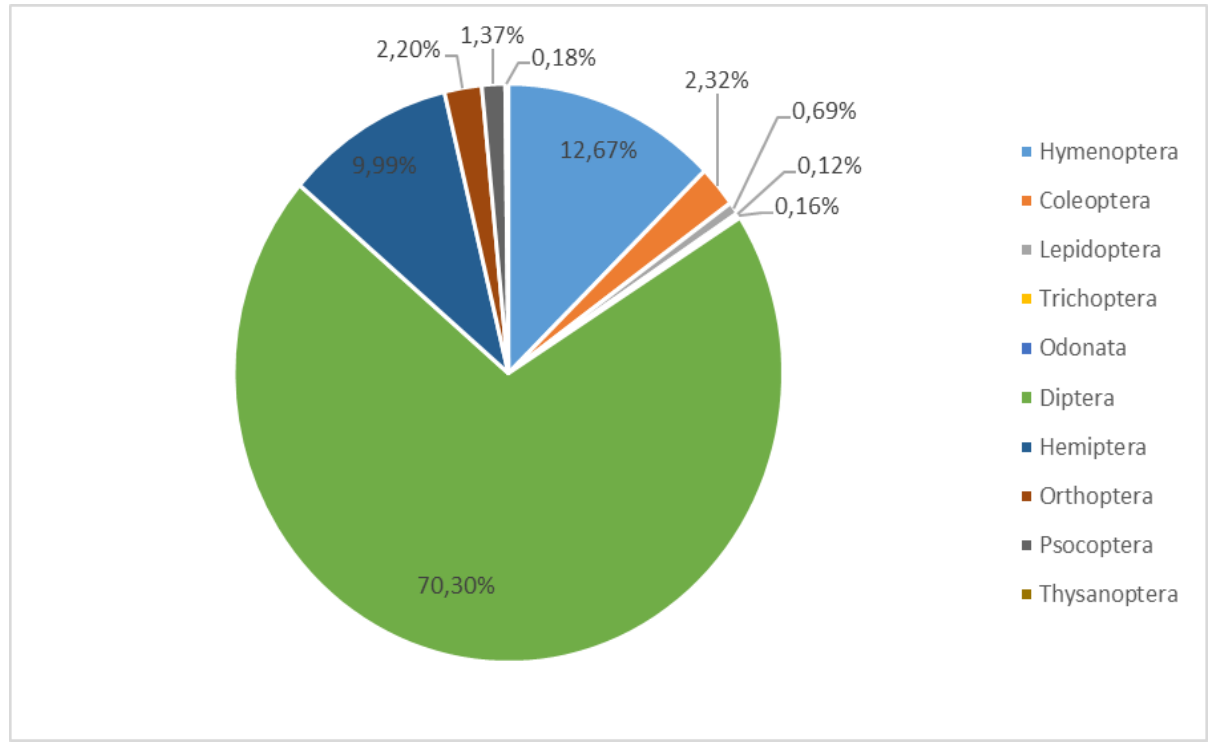

Figure 3. Percentage of insects order in research

\section{Family of Hymenoptera order and roles}

Insect from Hymenoptera order which successfully obtained in this research has different roles, such as parasitoid ( 22 families), predator ( 7 families), pollinator $(2$ families) and phytophage (1 family) (Table 4).

Table 4. Family of Hymenoptera order and roles

\begin{tabular}{cccccc}
\hline No. & Family & $\begin{array}{c}\text { Role of } \\
\text { Insect }\end{array}$ & No. & Family & $\begin{array}{c}\text { Role of } \\
\text { Insect }\end{array}$ \\
\hline 1 & Aphelinidae & Parasitoid & 17 & Pteromalidae & Parasitoid \\
2 & Bethylidae & Parasitoid & 18 & Scelionidae & Parasitoid \\
3 & Brachonidae & Parasitoid & 19 & Sclerogibbidae & Parasitoid \\
4 & Ceraphronidae & Parasitoid & 20 & Tetracampidae & Parasitoid \\
5 & Chrysididae & Parasitoid & 21 & Torymidae & Parasitoid \\
6 & Diapriidae & Parasitoid & 22 & Trichogrammatidae & Parasitoid \\
7 & Encyrtidae & Parasitoid & 23 & Amplulicidae & Predator \\
8 & Eucoilidae & Parasitoid & 24 & Crabronidae & Predator \\
9 & Eulophidae & Parasitoid & 25 & Formicidae & Predator \\
10 & Eupelmidae & Parasitoid & 26 & Nyssonidae & Predator \\
11 & Eurytomidae & Parasitoid & 27 & Pemphredonidae & Predator \\
12 & Evaniidae & Parasitoid & 28 & Philanthidae & Predator \\
13 & Ichneumonidae & Parasitoid & 29 & Sphecidae & Predator \\
14 & Mymaridae & Parasitoid & 30 & Apidae & Polinator \\
15 & Mymarommatidae & Parasitoid & 31 & Halictidae & Polinator \\
16 & Platygasteridae & Parasitoid & 32 & Agaonidae & Fitofag \\
\hline
\end{tabular}

Diversity of parasitoid insects from Hymenoptera order

The vegetable garden area has the high number of the parasitoid (378 individuals and 22 families) than rice field (160 individuals and 20 families) (Figure 3) (Table 4). In forward, Vegetable garden also has the highest value of diversity index $\left(\mathrm{H}^{\prime}=2,26\right.$ or moderate diversity) compared to parasitoid on rice field $\left(H^{\prime}=1.80\right.$ or average variety) (Table 5). 
Table 5. Diversity of parasitoid insect from Hymenoptera order

\begin{tabular}{cccc}
\hline \multirow{2}{*}{ Symbol } & \multicolumn{2}{c}{ Research Location } & \multirow{2}{*}{ Total } \\
\cline { 2 - 3 } & Rice Field & Vegetable Garden & \\
\hline N & 160 & 378 & 538 \\
F & 20 & 22 & 22 \\
$H^{\prime}$ & 1,80 & 2,26 & \\
E & 0,68 & 0,80 & \\
\hline
\end{tabular}

Information: $\mathrm{N}=$ Individual, $\mathrm{F}=$ Family, $\mathrm{H}^{\prime}$ = Diversity, and $\mathrm{E}=$ Evennes

\section{Discussion}

In general, the number of total insects obtained in this research based on three locations are 5037 individuals, originated from 10 order and 80 families (Table 3). Three dominant order of insects consists of Diptera $(70,30 \%)$, Hymenoptera $(12,67 \%)$ and Hemiptera (9,99\%) (Figure 2). Build upon the number of individuals, and rice field have the lowest number to Vegetable garden. Anderson et al. (2011), stated that the Hymenoptera parasitoid could be used as a group of insects used as an indicator of arthropod taxon richness in agricultural land, both rice fields plantation areas. According to Triwidodo (2003), The condition of the ecological system in the agroecosystem can be studied by looking at the composition of the role of individual species collected.

Furthermore, viewed from the number of insect family obtained, the Hymenoptera order was the most caught (32 families) insect than other orders. Table 2 and Table 3 show that although the most significant number of Diptera individuals were seen, however the use of malaise traps, buckets and insect nets, the diversity of the family of the order Hymenoptera was higher. This shows that the three collection tools used in this study are good tools for catching insects, especially from Hymenoptera Order. This result is appropriate to Atmowidi (2000) that the malaise traps, buckets, and insect nets are good collection tools and suitable for insect collection from Hymenoptera, especially parasitoid types. Futher, Campos et al. (2000) explained that bucket traps generally capture more parasitoid insects from Hymenoptera in a certain type of habitat.

Insect of Hymenoptera obtained in this study are 638 individuals from 32 families (Table 3 and 4). In the rice field, there are 160 individuals and in the Vegetable garden are 478 individuals (Table 2). The role of the Hymenoptera order is parasitoid, predator, pollinator and phytophage. Parasitoid (22 families) of Hymenoptera are odd compare to pretator (7 families), pollinator (2 families) and phytophage (1 family) (Table 4 ). The vegetable garden has more individual, family and order of Hymenoptera Parasitoid (2378 individual, 22 families) compared to the rice field (160 individuals and 20 families) (Figure 3) (Table 4).

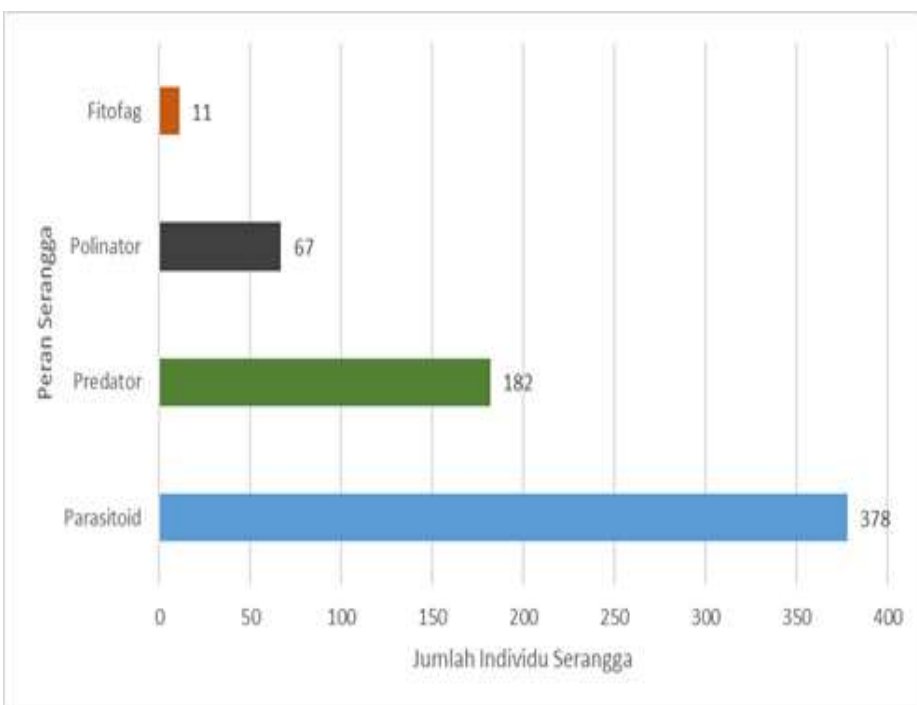

Figure 4. Number of individual insects from Hymenoptera order based on its roles

These results are similar to the diversity index $\left(\mathrm{H}^{\prime}\right)$ and distribution ( $E^{\prime}$ ) of parasitoid from Hymenoptera, which is Vegetable garden has high diversity index $\left(\mathrm{H}^{\prime}=2.26\right.$ and $\mathrm{E}$ $=0.080)$ and distribution compare to rice field $\left(\mathrm{H}^{\prime}=1.80\right.$ and $\mathrm{E}=0.68$ ) (Table 5). Vegetable gardens could be caused by high diversity in the plant, which is provided a place for parasitoid than rice. Perdana (2010) showed that park has more plants than rice fields, these plants are used as a place to live and a source of food for parasitoid hosts. In addition, rice fields are usually monoculture planting system. Hence the abundance of insects tends to be lower when compared to the cropping model in garden land with a polyculture system that mixes with wild plants (Kurniawati, 2015; Dirham and Trianto, 2020). This has corresponded with Anderson et al. (2011) that showed in vegetable gardens where there is the flower from wild plants in the crop, and it will increase the population of valuable insects, both predators and parasitoids. The diversity of species in wild plant habitats is inseparable from the availability of flowering plants that provide pollen and nectar as additional food for Hymenoptera parasitoids in each of these landscapes.

This states that species diversity tends to be low or moderate in ecosystems with decisive limiting factors and physically controlled environments and will increase in an ecosystem that is not regulated or occurs naturally. Rohman (2008) stated that the diversity of low to moderate Arthropods is influenced by several things, namely the related community is a fostered community whose existence is mainly managed by humans, the change in land use so that there is a change in living space for an organism, the microclimate in the ecosystem area, and occurs competition among the biota that inhabit the related ecosystem. In other words, the less diverse types of plants 
cause less varied food sources for parasitoid hosts so that the kinds of parasitoids that exist are less diverse.

\section{Conclusion}

Based on the analysis, the diversity of parasitoids from Hymenoptera in two research locations, namely rice fields $\left(\mathrm{H}^{\prime}=1.80\right)$ and vegetable gardens $\left(\mathrm{H}^{\prime}=2.26\right)$.

\section{Declaration statement}

The authors reported no potential conflict of interest.

\section{Acknowledgements}

We acknowledge to Forum Sains dan Teknologi (FOST), Himpunan Mahasiswa Pascasarjana, Universitas Gadjah Mada which has supported this publication.

\section{References}

Anderson, A., McCormack, S., Helden, A., Sheridan,H., Kinsella, A., \& Purvis, G. (2011). The potential of parasitoid Hymenoptera as bioindicators of arthropod diversity in agricultural grasslands. Journal of Applied Ecology, 48, 382-390.

Atmowidi, T. (2000). Keanekaragaman morfospesies Hymenoptera parasitoid dan senyawa antiherbivora Taman Nasional Gunung Halimun. Tesis. Bogor: Sekolah Pasca Sarjana, Departemen Proteksi Tanaman, Fakultas Pertanian, Institut Pertanian Bogor.

Borror, D. J., Triplehorn, C. A., \& Johnson, N. F. (1996). Pengenalan Pelajaran Serangga. Eds 6. Gadjah Mada University Press, penerjemah. Yogyakarta: UGM Press. Terjemahan dari An Introduction to the Study of Insects.

Brown, J. H. (2014). Why are there so many species in the tropics? Journal of Biogeography, 41, 8-22

Buchori, D. (2014). Pengendalian hayati dan konservasi serangga untuk pembangunan Indonesia hijau. Orasi ilmiah guru besar IPB. Bogor: Institut Pertanian Bogor.

Cadotte, M. W., Carscadden, K., \& Mirotchnick, N. (2011). Beyond species: functional diversity and the maintenance of ecological processes and services. Journal of Applied Ecology, 48, 1079-1087.

Campos, W. G., Pereira, D. B. S., \& Schoereder, J. H. (2000). Comparison of the efficiency of flight-interception trap models for sampling Hymenoptera and other insects. Soc Entomol Brasil, 29, 381-389.

Dirham, \& Trianto, M. (2020). Analisis isi lambung Ikan Mujair (Oreochromis mossambicus) di Perairan Danau Talaga Kabupaten Donggala. Jurnal BIO-EDU, 5(3), 118-128.
Gibson, G. A. P. (1993). Superfamily Mymarommatoidea and Chalcidoidea - Hymenoptera of the World: An identification guide to family. Ottawa: Canada Communication Group Publishing.

Hartina, S, dan Trianto, M. (2020). Keanekaragaman Zooplankton di Perairan Danau Lindu Provinsi Sulawesi Tengah. Jurnal BIO-EDU, 5(3), 129-139.

Kurniawati, N. (2015). Keragaman dan kelimpahan musuh alami Hama pada habitat padi yang dimanipulasi dengan tumbuhan berbunga. Ilmu Pertanian, 18, 31 36 .

Magurran, A. E. (1996). Ecologycal Diversity and Its Measurement. London: Chapman and Hall.

McAlpine, J. F. (1981). Manual of Neartic Diptera Volume 1. Ottawa: Agriculture Canada.

Nuraini, Trianto, M., Sukmawati, \& Marisa, F. (2020). Keanekaragaman sumber pakan dan perilaku mencari pakan lebah Tetragonula laeviceps (Hymenoptera: Meliponini) di Kecamatan Parigi Selatan. Jurnal BIOEDU, 5(3), 173-184.

Perdana, T. A. (2010). Keanekaragaman serangga hymenoptera (khususnya parasitoid) pada areal persawahan, kebun sayur dan hutan di daerah bogor. Thesis diterbitkan. Bogor: Institut Pertanian Bogor.

Pratama, A., \& Trianto, M. (2020). Keanekaragaman lichen di Hutan Mangrove Desa Tomoli Kabupaten Parigi Moutong. Jurnal BIO-EDU, 5(3), 140-150.

Sukmawati, Trianto, M., \& Nuraini. Hubungan kekerabatan intraspesies tanaman puring (Codiaeum variegatum L.) di Kecamatan Parigi Selatan berdasarkan analisis fenetik. Jurnal BIO-EDU, 5(3), 161-172.

Suprianto, Trianto, M., Alam, N., \& Kirana, N. G. A. G. C. (2020). Karakter morfologi dan analisis daerah conserved gen elongation factor 1a (EF1a) pada Lepidotrigona terminata. Jurnal Metamorfosa, 7(2), 30-39.

Trianto, M., \& Marisa, F. (2020). Diversity of bees and wasp (Hymenoptera) in cowpea (Vigna sinensis L.) in agricultural area at Martapura District, Banjar Regency, South Kalimantan. Journal of Science and Technology, 9(2), 29-33.

Trianto, M, \& Marisa, F. (2020). Studi kelimpahan dan pola sebaran Collembola pada tiga tipe penggunaan lahan di Kabupaten Banjar, Kalimantan Selatan. Jurnal BIO-EDU, 5(3), 107-117.

Trianto, M., \& Purwanto, H. (2020). Molecular phylogeny of stingless bees in the Special Region of Yogyakarta revealed using partial $16 \mathrm{~S}$ rRNA mitochondrial gene. Buletin Peternakan, 44(4), 186-193. 
Trianto, M., \& Purwanto, H. (2020). Morphological characteristics and morphometrics of Stingless Bees (Hymenoptera: Meliponini) in Yogyakarta, Indonesia. Biodiversitas, 21(6), 2619-2628.

Trianto, M., Kaini, Saliyem, Warsih, E., \& Winarsih. (2020). Keanekaragaman serangga polinator pada tanaman nanas (Ananas comosus (L.) Merr.) di Desa Bincau. Jurnal Penelitian Science dan Pendidikan, 9(2), 154162.

Trianto, M., Marisa, F., \& Siswandari, N. P. (2020). Kelimpahan nisbi, frekuensi, dan dominansi jenis lalat di beberapa Pasar Tradisional di Kecamatan Martapura. Jurnal Metamorfosa, 7(2), 21-29.

Trianto, M., Marisa, F., \& Sukmawati. (2020). Keanekaragaman jenis rayap pada perkebunan kelapa sawit dan perkebunan karet di Kabupaten Banjar, Kalimantan Selatan. Jurnal Biologi Makassar, 5(2), 199-209.

Triwidodo, H. (2003). Analisis agroekosistem. Makalah pada Lokakarya Biodiversitas di Institut Pertanian Bogor. Bogor.

Udawatta, R. P., Rankoth, L. M., \& Jose, S. (2019). Agroforestry and Biodiversity. Sustainability, 11, 2879.

Widnyana, I. K. (2012). Meningkatkan peranan musuh alami dalam pengendalian organisme penggganggu tumbuhan sesuai konsep PHT (Pengelolaan HamaPenyakit Terpadu). Bakti Saraswati, 1, 1-13. 